\title{
Erratum to: Abstracts of the WASAD Congress 2017, in conjunction with the Collaborative Research Centers SFB-TRR 58, Fear, Anxiety, Anxiety Disorders 14-16 September, Würzburg, Germany
}

\section{Peter Riederer $^{1}$}

Published online: 19 September 2017

(c) Springer-Verlag GmbH Austria 2017

\section{Erratum to: J Neural Transm}

DOI 10.1007/s00702-017-1777-9

This article was originally published with the wrong title. The correct title is:

Abstracts of the WASAD Congress 2017, in conjunction with the Collaborative Research Centers SFB-TRR 58, Fear, Anxiety, Anxiety Disorders 14-16 September, Würzburg, Germany

The online version of the original article can be found under doi:10.1007/s00702-017-1777-9.

\section{Peter Riederer}

peter.riederer@uni-wuerzburg.de

1 President, World Association for Stress Related and Anxiety Disorders e.V. (WASAD), Klinik und Poliklinik für

Psychiatrie und Psychotherapie, Klinische Neurochemie,

Universität Würzburg, Füchsleinstr. 15, 97080 Würzburg,

Germany 